\title{
Mammography wars
}

\author{
Fiona Godlee editor, BMJ
}

\begin{abstract}
A Canadian taskforce has just published revised guidelines on breast cancer screening (doi:10.1136/bmj.d7625). The recommendations mirror those from the US Preventive Services Taskforce: in women who aren't at high risk, don't start routine mammography until age 50, screen only every two to three years, and stop routine clinical breast examination.

The US guidelines met with fierce opposition when they were published in 2009, and the Canadian guidelines are already under fire. The fact that both of these national task forces have reached the same conclusion should give some confidence in the result, but there is no doubting the heat in this controversy. Nor are we dealing with a stationary target: new evidence is accruing all the time. Published online this week is a further contribution to the debate - a modelling study of mammography screening from France that suggests the harms may be lower than some have reported. The authors found a lower than expected rate of overdiagnosis of invasive cancer in women aged 50-69 (doi:10.1136/bmj.d7017).
\end{abstract}

At any rate, hard hats and thick skins will be in order for those brave souls who agree to work on the review of breast cancer screening recently announced in the $B M J$ by the UK's cancer tsar Mike Richards (doi:10.1136/bmj.d6843). Richards's plan is to establish an independent panel to review the evidence, but this hasn't met with much enthusiasm from $B M J$ readers. This week we publish some of your responses, which are liberal with their advice. Some focus on what should have been done before now-an evaluation of a risk adjusted approach to screening, says Michael Baum; collection of raw data from all trials, says Cornelia Baines. Others focus on the choice of co-chairs, who might appear to be biased towards screening, and the decision to exclude anyone from the panel who has published on this subject, which will exclude anyone who is critical of the current programme. Lesley Fallowfield speaks for many women when she admits that, despite her own detailed knowledge of the science, she is uncertain of the value of mammography screening. "I feel silly for attending screening, but scared not to do so."

If Mike Richards's heart is sinking, he might like to take the advice contained in two of this week's letters, and hand this hot potato over to NICE. Whether NICE would want to take it from him is another matter. But guideline producers can't expect a quiet life. NICE's new guidance on caesarean section was previewed in the UK press as offering caesarean section on demand. "Every mother-to-be will be given the right to have her baby by caesarean section-even if there is no medical need," announced The Mail on Sunday (www.dailymail.co.uk/ health/article-2055227/NHS-women-right-caesarean-sectionbirth-dont-need-it.html\#ixzz1eRQF7I5k). The actual guidance, published in summary this week, is rather more measured (doi:10.1136/bmj.d7108). It aims to ensure that all caesarean sections are "appropriate." One way to achieve this is to make sure that health professionals provide women with evidence based information on the risks and benefits. Sounds like NICE might be just the place for the mammography wars.

Cite this as: BMJ 2011;343:d7623

๑ BMJ Publishing Group Ltd 2011 